\title{
A COMPARATIVE STUDY OF OMRF \& SMRF STRUCTURAL SYSTEM FOR TALL \& HIGH RISE BUILDINGS SUBJECTED TO SEISMIC LOAD
}

\author{
G.V.S.SivaPrasad ${ }^{1}$, S. Adiseshu ${ }^{2}$ \\ ${ }^{1}$ M. Tech Scholar, ${ }^{2}$ Associate Professor, Department of Civil Engineering, \\ Andhra University College of Engineering (A), Visakhapatnam - 530 003, Andhra Pradesh, India, \\ gorasa_sivaprasad@rediffmail.com, siragamseshu@rediffmail.com
}

\begin{abstract}
The objective of this study is to investigate the seismic behavior of the structure i.e... OMRF (Ordinary moment resisting frame) \& SMRF (Special R C moment Resisting frame). For this purpose $5^{\text {th }}, 10^{\text {th }}, 15^{\text {th }}, 20^{\text {th }}$ storied structure were modeled and analysis was done using Staad.Pro software and using the codes for analysis, IS 1893:2002, IS 456: 2000. The study assumed that the buildings were located in seismic zone II (Visakhapatnam region).The study involves the design of alternate shear wall in a structural frame and its orientation, which gives better results for the OMRF \& SMRF structure constructed in and around Visakhapatnam region. The buildings are modeled with floor area of $600 \mathrm{sqm}(20 \mathrm{~m} \times 30 \mathrm{~m})$ with 5 bays along $20 \mathrm{~m}$ span each $4 \mathrm{~m}$. and 5 bays along the $30 \mathrm{~m}$ span each $6 \mathrm{~m}$. The design is carried out using STAAD.PRO software. Shear walls are designed by taking the results of the maximum value of the stress contour and calculation are done manually by using IS 456-2000 and IS 13920-1993. The displacements of the current level relative to the other level above or below are considered. The preferred framing system should meet drift requirements.
\end{abstract}

1. $\quad$ Up to 20 floored building subjected to seismic load for Visakhapatnam without shear wall

2. $\quad$ Up to 20 floored building subjected to seismic load for Visakhapatnam with shear wall

Key words: Seismic Behavior, Shear Wall, Orientation of shear wall, Story Drift, Serviceability. staad.pro

\section{INTRODUCTION}

The main aim of the present work is therefore to make a comparative study of OMRF \& SMRF structural system and orientation with the shear walls and without shear wall. The study is restricted to R.C. Structures only. Generally, the outside dimensions of individual member like slabs, beams and columns are chosen primarily from consideration of aesthetics and functional design, they are kept constant in the analysis. Only the quantity and cost of steel in both shear wall and without shear wall is to be taken as an indicator. Whether a building is provided with a shear wall or not, depends not only on the height of the building but also on the intensity of lateral loads. So it is proposed to carry out this comparison for two different structures in a Visakhapatnam city i.e... (Zone II).The principles for analysis of multi framed structures with shear wall \& without shear wall are quite well known, software packages are not available for design of shear wall systems, hence it is first necessary to develop efficient methods for analysis of framed building with shear walls.

The main aims of this present work are the following:

$\checkmark \quad$ The earth quake history of the Visakhapatnam city and its configuration which could serve the basis of comparison for the structure with \& without shear wall. $\checkmark \quad$ To model a structure for analyzing multistoried frame with shear wall, assuming a plate size of $1 \mathrm{~m} \times 1 \mathrm{~m}$ throughout the structure \& alternate shear wall, by establishing its values.

$\checkmark \quad$ To carry out analysis and design of the chosen building for height of 5,10,15,20 stories to be constructed in a Visakhapatnam district. ( zone II)

$\checkmark \quad$ To make an analysis and design for Drift values of the chosen high rise buildings.

$\checkmark \quad$ To provide guide lines for structural engineers on the serviceability and the economy aspects, that could be obtained by using shear wall.

\section{Codes Used for Design are}

1. DEAD LOADS IS 875 PART 1

2. LIVE LOADS IS 875 PART 2

3. SEISMIC LOADS IS1893-2000 PART 1

4. FOR REINFORCED STRUCTURES IS 456-2000

The building frame is modeled with a dimensions of $20 \mathrm{~m} \times 30$ $\mathrm{m}$ having columns \& beams with a slab panel of $4 \mathrm{~m} \times 6 \mathrm{~m}$ the model is made using STAAD.PRO Software. In case of building with shear wall the building frame is modeled as above dimensions only with alternate shear wall using 4 node 
plate proposed thickness of $200 \mathrm{~mm}$ along the height of the structure.

\section{PROJECT PHILOSOPHY}

\subsection{INTRODUCTIONS TO STRUCTURAL}

\section{SYSTEM}

This project presents the comparative study of the OMRF (ordinary moment resisting frame) \& SMRF (special RC moment resisting frame).The study involves the behavior of the ordinary framed structure and shear wall framed structural and orientation of the shear wall which gives the better results for the OMRF \& SMRF structure constructed in and around Visakhapatnam District. The buildings are modeled with floor area of $600 \mathrm{sqm}(20 \mathrm{~m} \mathrm{x} 30 \mathrm{~m})$ with 5 bays along $20 \mathrm{~m}$ span each $4 \mathrm{~m}$. and 5 bays along the $30 \mathrm{~m}$ span each $6 \mathrm{~m}$. The model is analyzed for high rise buildings located in Visakhapatnam city (zone II). A review of current design and construction practice forms the form work for the selection of the design variables and constants. The design is carried out using STAAD.PRO 2006 software. Shear wall are design by take the results of the maximum value of the stress contour and calculation are done manually by using IS 456-2000 and IS 13920-1993.the displacements of the other level relative to the other level above or below. The preferred framing system should meet drift requirements

\subsection{Earthquake Zones in India}

The India is divided into number of zones as per IS standards The varying geology at different locations in the country implies that the likelihood of damaging earthquakes taking place at different locations is different. Thus, a seismic zone map is required so that buildings and other structures located in different regions can be designed to withstand different level of ground shaking. The current zone map divides India into four zones - II, III, IV and V. Parts of Himalayan boundary in the north The seismic zone maps 1967 are revised from time to time as more understanding is gained on the geology, the seismo tectonics and the seismic activity in the country For instance, the Koyna earthquake of occurred in an area classified in zone Ias per map of 1966. The 1970 version of code upgraded the area around Koyna to zone IV. The Killari (Latur) earthquake of 1993 occurred in zone I (now in Zone III).

The new zone map places this area in zone III. The new zone map will now have only four seismic zones - II, III, IV and V. The areas falling in seismic zone $I$ in the current map are merged with those of seismic zone II. Also, the seismic zone map in the peninsular region is being modified. Madras will come under seismic zone III as against zone II currently. The national Seismic Zone Map presents a large scale view of the seismic zones in the country. Local variations in soil type and geology cannot be represented at that scale. Therefore, for important projects, such as a major dam or a nuclear power plant, the seismic hazard is evaluated specifically for that site. Also, for the purposes of urban planning, metropolitan areas are micro zoned. Seismic micro zonation accounts for local variations in geology, local soil profile, etc

\section{History of Seismic Zone Map of India: 1962, 1966, 1970}

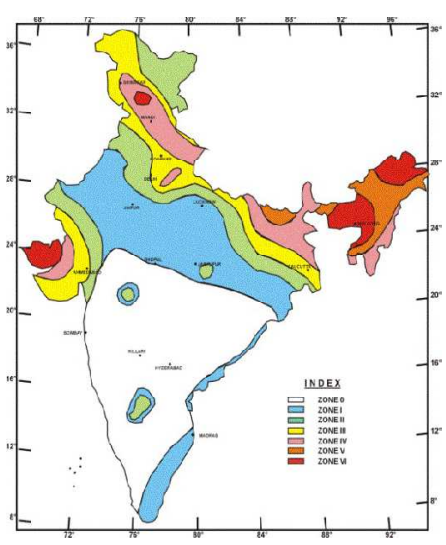

Figure A 1962 India map

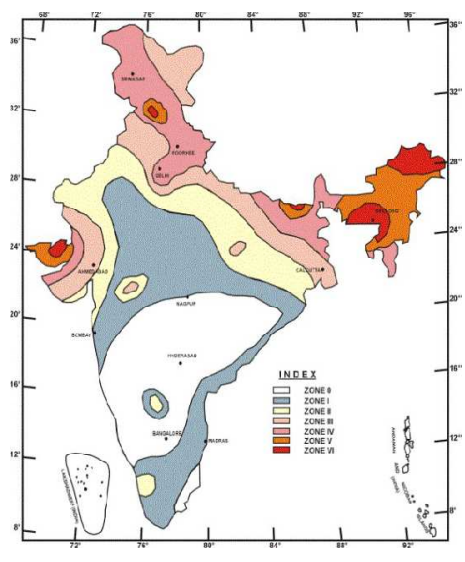

Figure B 1966 India map

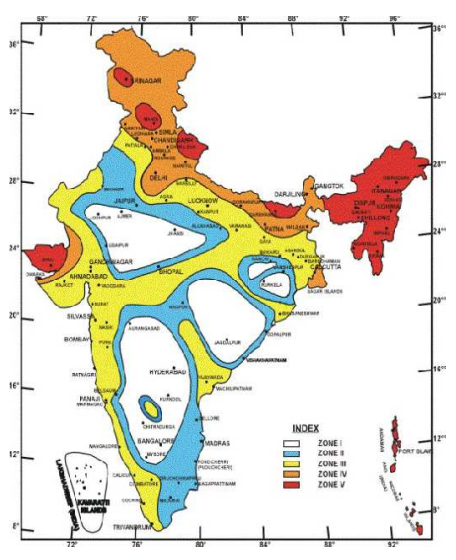

Figure C 1970 India map

Recent Map indicating Earthquakes Zones in India (IS 1893 - 2002) 


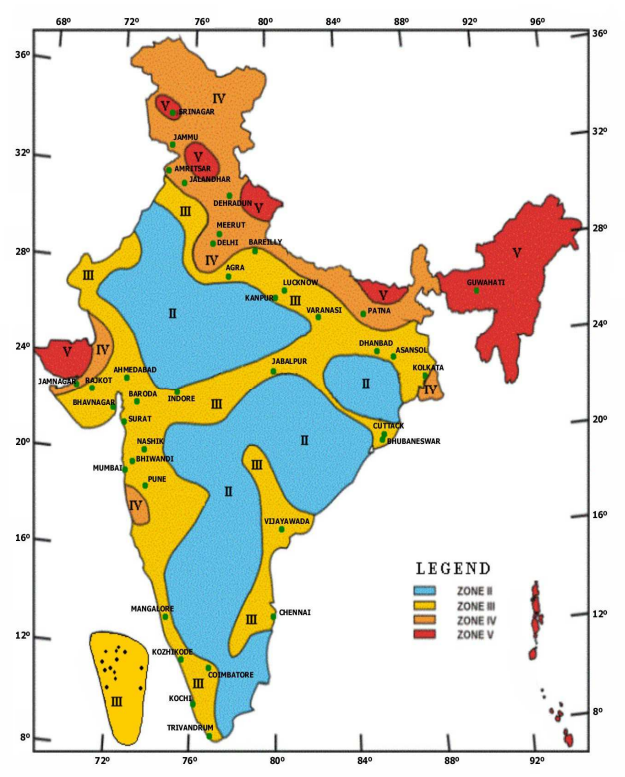

Figure D 1983-2002 India map

\subsection{Discussions on Model Making}

The basic steps involved in the model making are:-

1. Taking the past history of the earthquake in zone II (Visakhapatnam).

2. Basic model specifications.

3. Modeling of alternate shear wall and moment resisting system.

4. Force analysis design.

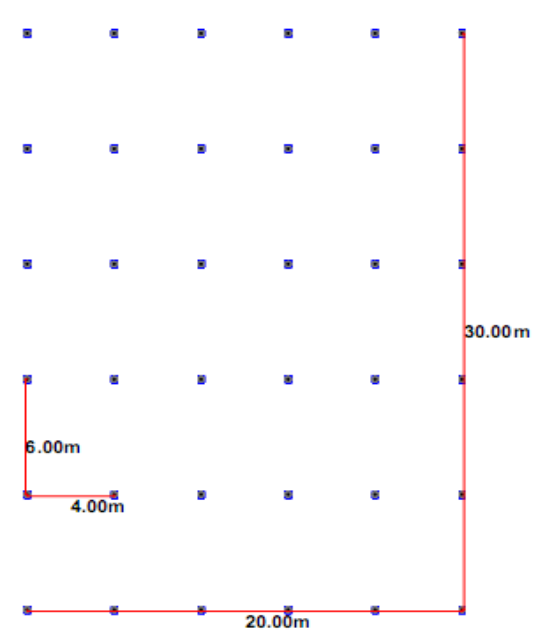

5. Orientation of the shear wall.

6. Comparison of OMRF \& SMRF structures.

The plan and elevation detail of the 20 storey structure are shown in fig. The analysis of any statically in-determined structure like a frame demand prior knowledge of dimensions of individual columns and beams of all the floor levels.

Fig 15 storey structure 

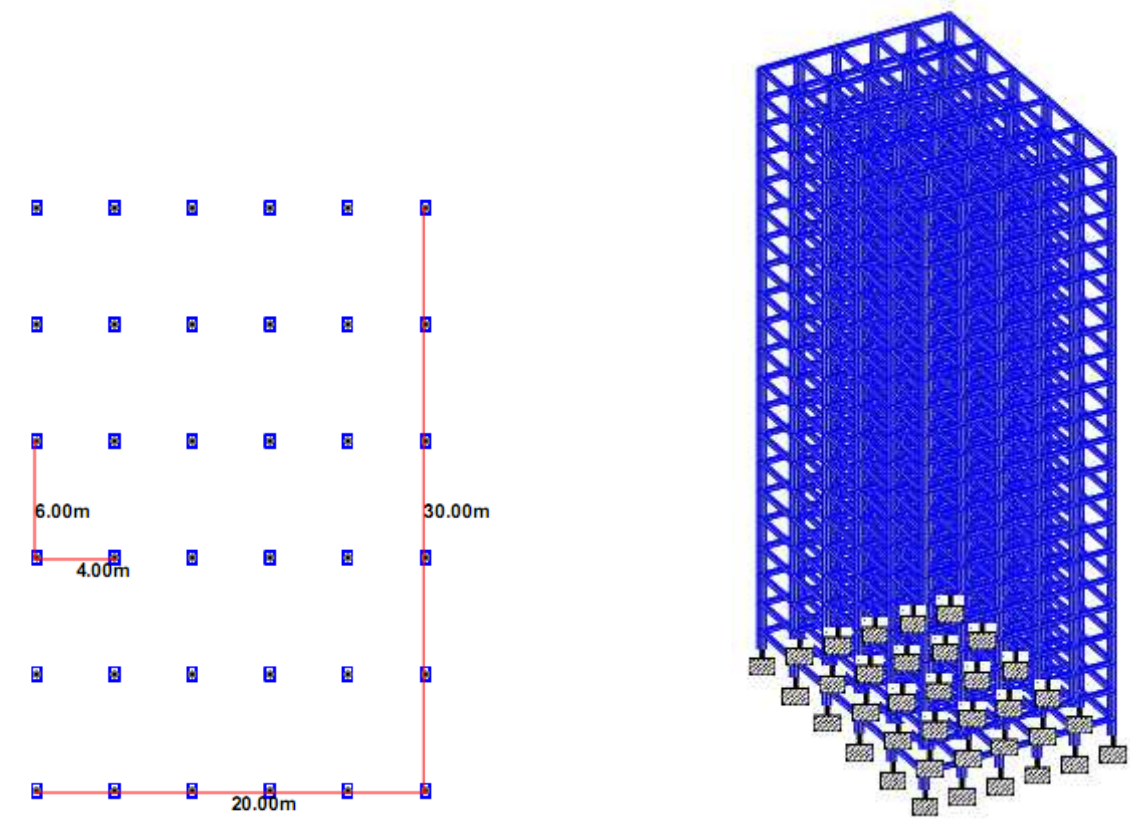

Fig 220 storey structure

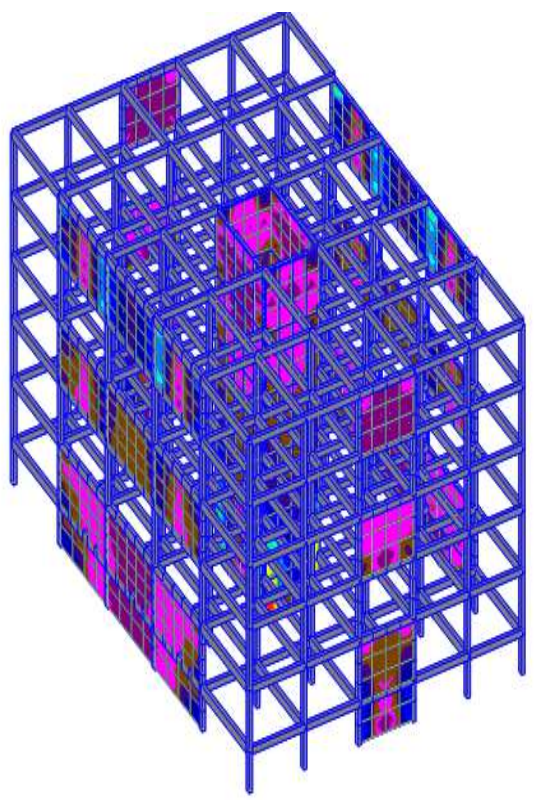

Fig 3 Shear wall framed structure elevation

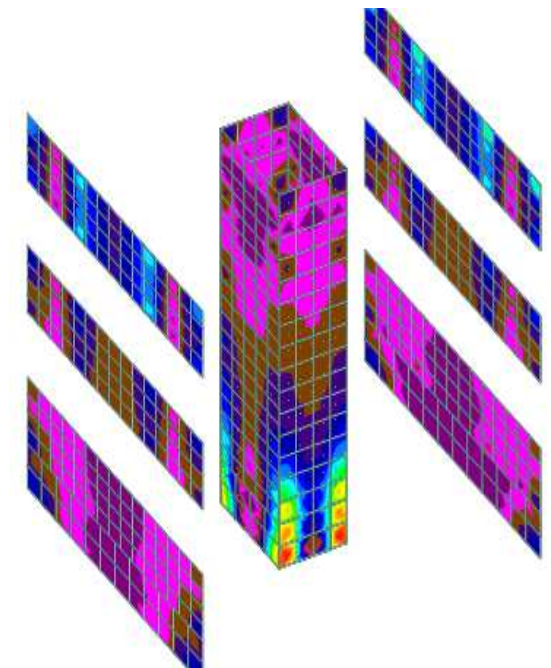

Fig 4 Stress contour diagram form the analysis
For this purpose the dimensions have been fixed through preliminary simplified calculation of axial loads coming on columns at different floor levels and bending moment in beams in a typical floor levels under the action of vertical loads OMRF structural system

Here

Columns

$$
-\mathrm{C}
$$

$\begin{array}{ll}\text { Beam Size B } & - \text { B x D } \\ \text { Slab Thickness } & -140 \mathrm{~mm} \\ \text { Grade Of Concrete } & - \text { M 30 } \\ \text { Grade Of Steel Is } & - \text { Fe } 500 \\ \text { Shear Wall Thickness } & -200 \mathrm{~mm} \\ \mathrm{~F}_{\mathrm{ck}} & -30 \mathrm{~N} / \mathrm{mm}^{2} \\ \mathrm{~F}_{\mathrm{y}} & -500 \mathrm{~N} / \mathrm{mm}^{2}\end{array}$




\section{For 5 storey structure}

Table1

\begin{tabular}{|c|l|c|c|c|}
\hline Range & $\begin{array}{c}\text { Column } \\
\text { size } \\
\mathrm{Mm}\end{array}$ & $\begin{array}{c}\text { B1 } \\
\text { Beam } \\
\text { size } \\
\text { B x D }\end{array}$ & $\begin{array}{c}\text { B2 } \\
\text { Beam size } \\
\text { B x D }\end{array}$ & $\begin{array}{c}\text { Slab } \\
\text { thickness }\end{array}$ \\
\hline $\begin{array}{c}\text { Up to } \\
5 \\
\text { floors }\end{array}$ & $\begin{array}{l}350 \times \\
550\end{array}$ & $300 \times 500$ & $300 \times 600$ & $140 \mathrm{~mm}$ \\
\hline
\end{tabular}

\section{For 10 storey structure}

\section{Table2}

\begin{tabular}{|c|l|c|c|c|}
\hline Range & $\begin{array}{c}\text { Column } \\
\text { size }\end{array}$ & $\begin{array}{c}\text { B1 } \\
\text { Beam } \\
\text { size } \\
\text { B x D }\end{array}$ & $\begin{array}{c}\text { B2 } \\
\text { Beam size } \\
\text { B x D }\end{array}$ & $\begin{array}{c}\text { Slab } \\
\text { thickness }\end{array}$ \\
\hline $\begin{array}{c}\text { Up to } \\
5 \\
\text { floors }\end{array}$ & $\begin{array}{l}450 \times \\
750\end{array}$ & $300 \times 500$ & $300 \times 600$ & $140 \mathrm{~mm}$ \\
\hline
\end{tabular}

\section{For 15 storey structure}

Table 3

\begin{tabular}{|c|c|c|c|c|}
\hline Range & $\begin{array}{c}\text { Column } \\
\text { size }\end{array}$ & $\begin{array}{c}\text { B1 } \\
\text { Beam size } \\
\text { B x D }\end{array}$ & $\begin{array}{c}\text { B2 } \\
\text { Beam } \\
\text { size } \\
\text { B x D }\end{array}$ & $\begin{array}{c}\text { Slab } \\
\text { thickness }\end{array}$ \\
\hline $\begin{array}{c}\text { Up to 5 } \\
\text { floors }\end{array}$ & $400 \times 1200$ & $300 \times 500$ & $\begin{array}{c}300 \times \\
600\end{array}$ & $140 \mathrm{~mm}$ \\
\hline
\end{tabular}

For 20 storey structure

Table 4

\begin{tabular}{|c|c|c|c|c|}
\hline Range & $\begin{array}{c}\text { Column } \\
\text { size }\end{array}$ & $\begin{array}{c}\text { B1 } \\
\text { Beam size } \\
\text { B } \times \text { D }\end{array}$ & $\begin{array}{c}\text { B2 } \\
\text { Beam } \\
\text { size } \\
\text { B x D }\end{array}$ & $\begin{array}{c}\text { Slab } \\
\text { thickness }\end{array}$ \\
\hline $\begin{array}{c}\text { Up to 5 } \\
\text { floors }\end{array}$ & $500 \times 1300$ & $300 \times 500$ & $300 \times 600$ & $140 \mathrm{~mm}$ \\
\hline
\end{tabular}

All dimensions are in $\mathrm{mm}$. The above tables are the dimensions of the Ordinary Moment Resisting Frame structure subjected to seismic load in Visakhapatnam region

The dimensions for the 5,10,15,20 stored building are as given below:-

SMRF structural system

Here

Columns

Beam Size B1\&B2

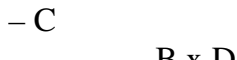

Slab Thickness

Grade Of Concrete

$-140 \mathrm{~mm}$

Grade Of Steel Is

Shear Wall Thickness

$\mathrm{F}_{\mathrm{ck}}$

$\mathrm{F}_{\mathrm{y}}$

- Fe 500

$-200 \mathrm{~mm}$

- $30 \mathrm{~N} / \mathrm{mm}^{2}$

$-500 \mathrm{~N} / \mathrm{mm}^{2}$

For 5 storey structure

Table 5

\begin{tabular}{|c|c|c|c|c|c|}
\hline Range & $\begin{array}{c}\text { Column } \\
\text { size }\end{array}$ & $\begin{array}{c}\text { B1 } \\
\text { Beam } \\
\text { size } \\
\text { B x D }\end{array}$ & $\begin{array}{c}\text { B2 } \\
\text { Beam } \\
\text { size } \\
\text { B x D }\end{array}$ & $\begin{array}{c}\text { Slab } \\
\text { thickness }\end{array}$ & $\begin{array}{c}\text { Shear wall } \\
\text { thickness }\end{array}$ \\
\hline $\begin{array}{c}\text { Up to } \\
5 \\
\text { floors }\end{array}$ & $\begin{array}{c}350 \mathrm{x} \\
550\end{array}$ & $\begin{array}{c}300 \mathrm{x} \\
450\end{array}$ & $\begin{array}{c}300 \mathrm{x} \\
500\end{array}$ & 140 & 200 \\
\hline
\end{tabular}

For 10 storey structure

Table 6

\begin{tabular}{|c|c|c|c|c|c|}
\hline Range & $\begin{array}{c}\text { Column } \\
\text { size }\end{array}$ & $\begin{array}{c}\text { B1 } \\
\text { Beam } \\
\text { size } \\
\text { B x D }\end{array}$ & $\begin{array}{c}\text { B2 } \\
\text { Beam } \\
\text { size } \\
\text { B x D }\end{array}$ & $\begin{array}{c}\text { Slab } \\
\text { thicknes } \\
\text { s }\end{array}$ & $\begin{array}{c}\text { Shear } \\
\text { wall } \\
\text { thickness }\end{array}$ \\
\hline $\begin{array}{c}\text { Up to } \\
10 \\
\text { floors }\end{array}$ & $\begin{array}{c}450 \times \\
750\end{array}$ & $\begin{array}{c}300 \times \\
450\end{array}$ & $\begin{array}{c}300 \times \\
500\end{array}$ & 140 & 200 \\
\hline
\end{tabular}

\section{For 15 storey structure}

Table 7

\begin{tabular}{|c|c|c|c|c|c|}
\hline Range & $\begin{array}{c}\text { Column } \\
\text { size }\end{array}$ & $\begin{array}{c}\text { B1 } \\
\text { Beam } \\
\text { size } \\
\text { B x D }\end{array}$ & $\begin{array}{c}\text { B2 } \\
\text { Beam } \\
\text { size } \\
\text { B x D }\end{array}$ & $\begin{array}{c}\text { Slab } \\
\text { thickness }\end{array}$ & $\begin{array}{c}\text { Shear } \\
\text { wall } \\
\text { thickness }\end{array}$ \\
\hline Up to & $500 \mathrm{x}$ & $300 \mathrm{x}$ & $300 \mathrm{x}$ & 140 & 200 \\
15 floors & 1300 & 450 & 500 & & \\
\hline
\end{tabular}

\section{For 20 storey structure}

\section{Table 8}

\begin{tabular}{|c|c|c|c|c|c|}
\hline Range & $\begin{array}{c}\text { Column } \\
\text { size }\end{array}$ & $\begin{array}{c}\text { B1 } \\
\text { Beam } \\
\text { size } \\
\text { B x D }\end{array}$ & $\begin{array}{c}\text { B2 } \\
\text { Beam } \\
\text { size } \\
\text { B x D }\end{array}$ & $\begin{array}{c}\text { Slab } \\
\text { thicknes } \\
\text { s }\end{array}$ & $\begin{array}{c}\text { Shear } \\
\text { wall } \\
\text { thickness }\end{array}$ \\
\hline $\begin{array}{c}\text { Up to } \\
20\end{array}$ & $600 \times$ & $300 \times$ & $300 \times$ & 140 & 200 \\
floors & 1500 & 450 & 500 & & \\
\hline
\end{tabular}


All dimensions are in $\mathrm{mm}$. The above tables are the dimensions of the Special R C Moment Resisting Frame having alternate shear wall subjected to seismic load in Visakhapatnam region

\subsection{Loading considerations for Design:-}

Design live load intensity is taken as $-3 \mathrm{kn} / \mathrm{m}^{2}$

Seismic loads

-IS: $1893-2002$

-IS: $1893-1984$

Dead loads

-IS: 875 (PART -I)

Live loads

-IS: 875 (PART -II)

Visakhapatnam region -zone factor is 0.1 (for Zone II)

Importance Factor -I=1

OMRF -Response Reduction Factor Is 3 SMRF

Response Reduction Factor Is 5

\subsection{LOAD COMBINATIONS CONSIDERED:-}

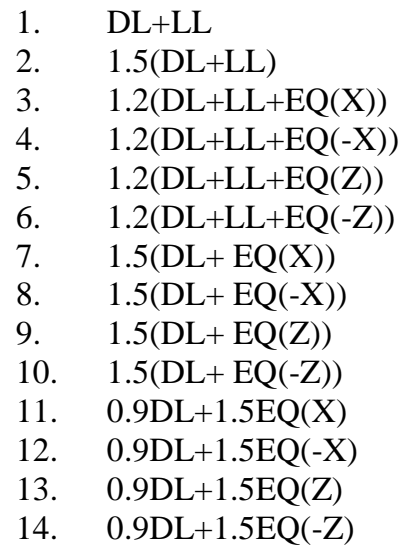

\subsection{ANALYSIS}

The structure with different framing system has been modeled using STAAD.PRO software with the above mentioned load conditions and combinations. The analysis is done for both the Ordinary Moment Resisting Frame \& Special R C Moment Resisting Frame, where as the analysis of a multi-storied frame or vertical as well as lateral loads is a straight forward affair, incorporation of shear wall into the system with commercially available STAAD.PRO was not that easy. Hence a number of alternative methods need to be tried out and arrived at a satisfactory method for the analysis of a frame attached to shear walls.

\section{Ordinary Moment Resisting Frame:}

It includes the beams \& columns along with fixed supports. These columns and beams are created with beam node elements and connected with beam elements of the software. Here the slab loading at each floor level is acting vertically on the slab and is calculated for square meter as its applied on the beam and the wall load is also assigned on the beams only . for horizontal loads, the physically present phenomena that the floor slab at each floor level is acting as very rigid horizontal beams which ensures that the lateral deformation of all the nodes at any particular floor level are the same. This is known as diaphragm action of the horizontal slabs.

\section{Special R C Moment Resisting Frame:}

It includes the columns and beams as the framing system but with four sides alternate shear walls on the structure on all the side instead of columns.

Method Using 4 Noded Plate Elements for Shear Wall: Here the shear wall was created using 4 noded plate elements and cross section of each element is $1 \mathrm{~m} \times 1 \mathrm{~m} \times 0.2 \mathrm{~m}$ and analysis was done

\section{RESULTS \& DISCUSSIONS BEHAVIOR OF OMRF \& SMRF STRUCTURAL SYSTEM}

The behavior of OMRF \& SMRF is taken as a basic study on the structures constructed in Visakhapatnam region and the previous history of the earth quake occurred in this region. The later forces resisting system is done for each building categorized based on lateral loads, lateral drifts, orientation of the shear wall $\&$ material quantity in terms of steel reinforcement alone. The modeled frame is a multi storied structure with a $20 \mathrm{~m} \times 30 \mathrm{~m}$ (rectangular plan) and area of $600 \mathrm{sqm}$ which have a bay of $4 \mathrm{~m} \mathrm{x}$ $6 \mathrm{~m}$.Lateral forces considered in seismic area Visakhapatnam region (zone -II).Lateral drift/deflections are checked against the requirements of clause 7.11.1 of IS-1893-2002 i.e. under transient seismic load. The lateral sway at the top should not exceed $0.004 \times h_{i}$, where $h_{i}$ is the storey height of the $i^{\text {th }}$ floor; Deflections are discussed below for the OMRF \&SMRF structural system for Visakhapatnam region (zone - II)

\subsection{Comparison of Deflection for OMRF \& SMRF}

\section{Structures}

The deflection results that are coming from the OMRF and SMRF frame modeled in staad.pro 2006 for the $5^{\text {th }}, 10^{\text {th }}, 15^{\text {th }}, 20^{\text {th }}$ storied structures with ordinary frame and shear wall frame, which is modeled as a $1 \mathrm{~m} \times 1 \mathrm{~m} \times 0.2 \mathrm{~m}$ plate and the analysis is done. From the analysis the plate stress contours are taken as results for design of an alternate shear wall.

In order to ascertain the simplest yet reliable method for analysis the combined action of frame plus shear wall for a load combination of

$$
\begin{aligned}
& \text { 1. } \\
& \text { 2. } \\
& 0.9 \mathrm{DL}+1.5 \mathrm{EQ}+1.5 \mathrm{EQ}(\mathrm{Z})
\end{aligned}
$$

Deflections of OMRF \& SMRF systems for Visakhapatnam region 
Load combination $=0.9 \mathrm{DL}+1.5 \mathrm{EQ}(\mathrm{X})$

Table 1 Five Storey structures

\begin{tabular}{|c|c|c|}
\hline Floor & OMRF system & SMRF system \\
\hline & $\mathrm{x}-$ trans cm & $\mathrm{x}-$ trans cm \\
\hline 0 & 0.0000 & 0.0000 \\
\hline 1 & 0.0809 & 0.0064 \\
\hline 2 & 0.3471 & 0.0265 \\
\hline 3 & 0.6174 & 0.1005 \\
\hline 4 & 0.8629 & 0.1247 \\
\hline 5 & 1.0597 & 0.1855 \\
\hline 6 & 1.1791 & 0.2046 \\
\hline
\end{tabular}

Load combination $=0.9 \mathrm{DL}+1.5 \mathrm{EQ}(\mathrm{z})$

Table 2 Five Storey structures

\begin{tabular}{|c|c|c|}
\hline Floor & OMRF system & SMRF system \\
\hline & $\mathrm{z}-$ trans cm & $\mathrm{z}-$ trans $\mathrm{cm}$ \\
\hline 0 & 0.0000 & 0.0000 \\
\hline 1 & 0.0724 & 0.0064 \\
\hline 2 & 0.3277 & 0.0265 \\
\hline 3 & 0.6195 & 0.1005 \\
\hline 4 & 0.8903 & 0.1247 \\
\hline 5 & 1.1072 & 0.1855 \\
\hline 6 & 1.2483 & 0.2046 \\
\hline
\end{tabular}

Load combination $=0.9 \mathrm{DL}+1.5 \mathrm{EQ}(\mathrm{X})$

Table 3 Ten Storey structures

\begin{tabular}{|c|c|c|}
\hline Floor & OMRF system & SMRF system \\
\hline & x- trans mm & x - trans mm \\
\hline 0 & 0.0000 & 0.0000 \\
\hline 1 & 0.0856 & 0.0176 \\
\hline 2 & 0.3760 & 0.0899 \\
\hline 3 & 0.6978 & 0.2005 \\
\hline 4 & 1.0215 & 0.3090 \\
\hline 5 & 1.3390 & 0.4414 \\
\hline 6 & 1.6434 & 0.5631 \\
\hline 7 & 1.9271 & 0.6900 \\
\hline 8 & 2.1808 & 0.8260 \\
\hline 9 & 2.3942 & 0.9521 \\
\hline 10 & 2.5560 & 1.0754 \\
\hline 11 & 2.6577 & 1.1905 \\
\hline
\end{tabular}

Load combination $=0.9 \mathrm{DL}+1.5 \mathrm{EQ}(\mathrm{z})$

Table 4 Ten Storey structures

\begin{tabular}{|c|c|c|}
\hline Floor & OMRF system & SMRF system \\
\hline & $\mathrm{z}$ - trans $\mathrm{mm}$ & $\mathrm{z}$ - trans $\mathrm{mm}$ \\
\hline 0 & 0 & 0 \\
\hline
\end{tabular}

\begin{tabular}{|c|c|c|}
\hline 1 & 0.0909 & 0.0665 \\
\hline 2 & 0.4411 & 0.0285 \\
\hline 3 & 0.8993 & 0.0905 \\
\hline 4 & 1.3917 & 0.1206 \\
\hline 5 & 1.8841 & 0.1866 \\
\hline 6 & 2.3564 & 0.2184 \\
\hline 7 & 2.7927 & 0.2515 \\
\hline 8 & 3.1783 & 0.3108 \\
\hline 9 & 3.499 & 0.3432 \\
\hline 10 & 3.7444 & 0.3897 \\
\hline 11 & 3.9158 & 0.4157 \\
\hline
\end{tabular}

Load combination $=0.9 \mathrm{DL}+1.5 \mathrm{EQ}(\mathrm{X})$

Table 5 Fifteen Storey structures

\begin{tabular}{|c|c|c|}
\hline Floor & OMRF system & SMRF system \\
\hline & $\mathrm{x}$ - trans $\mathrm{mm}$ & $\mathrm{x}-$ trans $\mathrm{mm}$ \\
\hline 0 & 0.0000 & 0.0000 \\
\hline 1 & 0.0614 & 0.0197 \\
\hline 2 & 0.2815 & 0.1028 \\
\hline 3 & 0.5441 & 0.2259 \\
\hline 4 & 0.8170 & 0.3539 \\
\hline 5 & 1.0919 & 0.5055 \\
\hline 6 & 1.3654 & 0.6534 \\
\hline 7 & 1.6347 & 0.8005 \\
\hline 8 & 1.8972 & 0.9804 \\
\hline 9 & 2.1493 & 1.1467 \\
\hline 10 & 2.3889 & 1.3209 \\
\hline 11 & 2.6105 & 1.4856 \\
\hline 12 & 2.8115 & 1.6499 \\
\hline 13 & 2.9863 & 1.8124 \\
\hline 14 & 3.1308 & 1.9669 \\
\hline 15 & 3.2407 & 2.1126 \\
\hline 16 & 3.3156 & 2.2547 \\
\hline
\end{tabular}

Load combination $=0.9 \mathrm{DL}+1.5 \mathrm{EQ}(\mathrm{z})$

Table 6 Fifteen Storey structures

\begin{tabular}{|c|c|c|}
\hline Floor & $\begin{array}{c}\text { OMRF system } \\
\mathrm{z}-\text { trans } \mathrm{mm}\end{array}$ & $\begin{array}{c}\text { SMRF system } \\
\mathrm{z}-\text { trans } \mathrm{mm}\end{array}$ \\
\hline & 0.0000 & 0.0000 \\
\hline 0 & 0.0452 & 0.0070 \\
\hline 2 & 0.2427 & 0.0324 \\
\hline 3 & 0.5471 & 0.1002 \\
\hline 4 & 0.9198 & 0.1423 \\
\hline 5 & 1.3338 & 0.2210 \\
\hline 6 & 1.7696 & 0.2690 \\
\hline 7 & 2.2650 & 0.3204 \\
\hline 8 & 2.6518 & 0.4056 \\
\hline 9 & 3.0774 & 0.4619 \\
\hline 10 & 3.4816 & 0.5456 \\
\hline 11 & 3.8576 & 0.6000 \\
\hline
\end{tabular}




\begin{tabular}{|l|l|l|}
\hline 12 & 4.1998 & 0.6542 \\
\hline 13 & 4.5043 & 0.7249 \\
\hline 14 & 4.7695 & 0.7758 \\
\hline 15 & 4.9975 & 0.8349 \\
\hline 16 & 5.1976 & 0.8802 \\
\hline
\end{tabular}

Load combination $=0.9 \mathrm{DL}+1.5 \mathrm{EQ}(\mathrm{X})$

Table 7 Twenty storey structure

\begin{tabular}{|c|c|c|}
\hline Floor & OMRF system & SMRF system \\
\hline & $\mathrm{x}$ - trans $\mathrm{mm}$ & $\mathrm{x}-$ trans $\mathrm{mm}$ \\
\hline 0 & 0.0000 & 0.0000 \\
\hline 1 & 0.0630 & 0.0215 \\
\hline 2 & 0.3174 & 0.1184 \\
\hline 3 & 0.6662 & 0.2818 \\
\hline 4 & 1.0574 & 0.4240 \\
\hline 5 & 1.4671 & 0.6051 \\
\hline 6 & 1.8840 & 0.7924 \\
\hline 7 & 2.3020 & 0.9949 \\
\hline 8 & 2.7173 & 1.2128 \\
\hline 9 & 3.1269 & 1.4325 \\
\hline 10 & 3.5280 & 1.6625 \\
\hline 11 & 3.9178 & 1.8866 \\
\hline 12 & 4.2932 & 2.1160 \\
\hline 13 & 4.6512 & 2.3447 \\
\hline 14 & 4.9883 & 2.5683 \\
\hline 15 & 5.3010 & 2.7878 \\
\hline 16 & 5.5853 & 2.9978 \\
\hline 17 & 5.8377 & 3.1710 \\
\hline 18 & 6.0545 & 3.4560 \\
\hline 19 & 6.2331 & 3.4837 \\
\hline 20 & 6.3732 & 3.6308 \\
\hline 21 & 6.4802 & 3.7691 \\
\hline & & \\
\hline
\end{tabular}

Load combination $=0.9 \mathrm{DL}+1.5 \mathrm{EQ}(\mathrm{z})$

Table 8 Twenty storey structure

\begin{tabular}{|c|c|c|}
\hline Floor & OMRF system & SMRF system \\
\hline & z- trans mm & z-trans mm \\
\hline 0 & 0.0000 & 0.0000 \\
\hline 1 & 0.0336 & 0.0070 \\
\hline 2 & 0.1826 & 0.0300 \\
\hline 3 & 0.4165 & 0.0920 \\
\hline 4 & 0.7080 & 0.1320 \\
\hline 5 & 1.0377 & 0.2070 \\
\hline 6 & 1.3919 & 0.2540 \\
\hline 7 & 1.7603 & 0.3050 \\
\hline 8 & 2.1353 & 0.3900 \\
\hline 9 & 2.5109 & 0.4490 \\
\hline 10 & 2.8819 & 0.5360 \\
\hline 11 & 3.2441 & 0.5950 \\
\hline 12 & 3.5938 & 0.6560 \\
\hline
\end{tabular}

\begin{tabular}{|l|l|l|}
\hline 13 & 3.9273 & 0.7450 \\
\hline 14 & 4.2416 & 0.8080 \\
\hline 15 & 4.5336 & 0.8960 \\
\hline 16 & 4.8009 & 0.9590 \\
\hline 17 & 5.0146 & 1.0770 \\
\hline 18 & 5.2549 & 1.1450 \\
\hline 19 & 5.4413 & 1.1940 \\
\hline 20 & 5.6034 & 1.2510 \\
\hline 21 & 5.7473 & 1.2950 \\
\hline
\end{tabular}

From Table 1 Comparison of $5^{\text {th }}$ storey deflection for OMRF \& SMRF structures in $\mathrm{X}$ directions

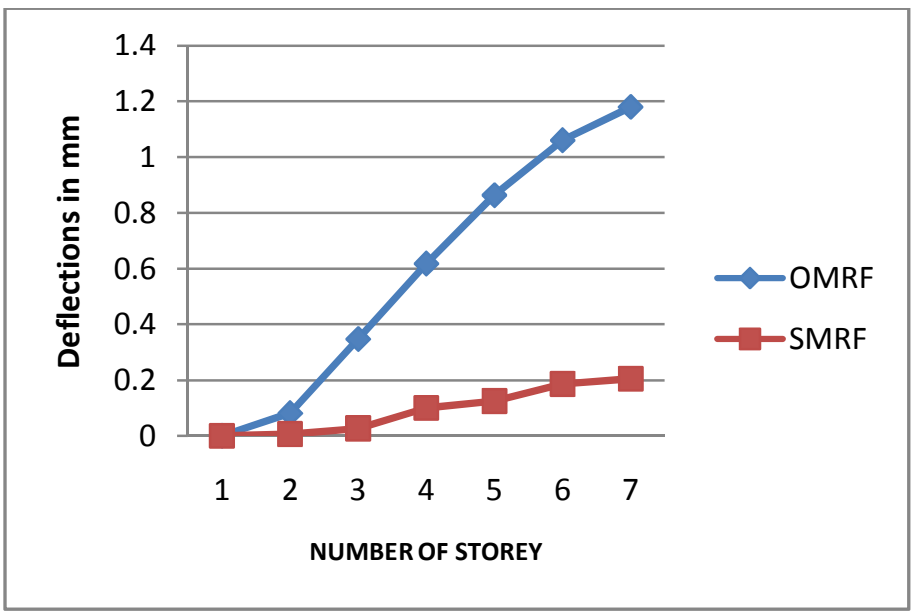

Figure 5 Deflections for OMRF \& SMRF

From Table 2 Comparison of $5^{\text {th }}$ storey deflection for OMRF \& SMRF structures in $\mathrm{Z}$ directions

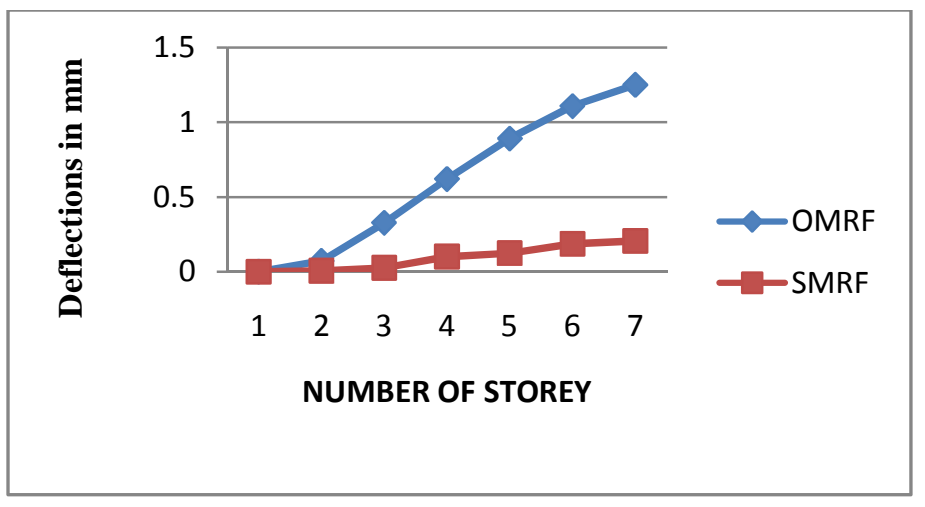

Figure 6 Deflections for OMRF \& SMRF

From the above results that are taken from the story drift, the values for $5^{\text {th }}$ storey $\&$ structure the deflection that are coming from the OMRF structures are not more safer when compared to SMRF structure 
From Table 3 Comparison of $10^{\text {th }}$ storey deflection for OMRF \& SMRF structures in $\mathrm{X}$ directions

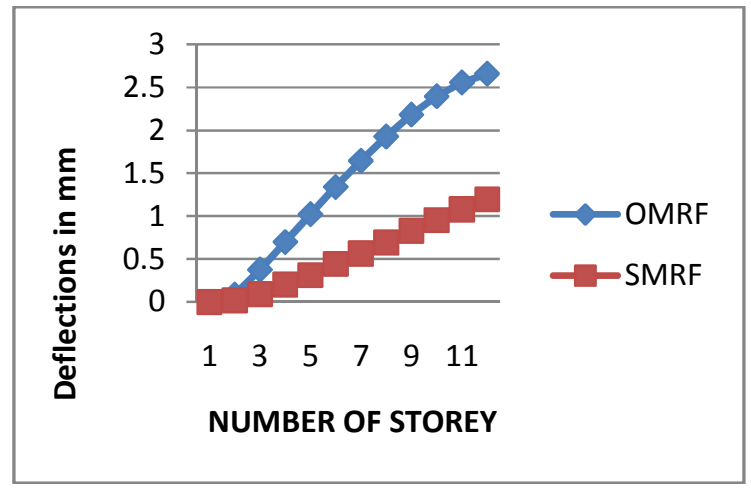

Figure 7 Deflections for OMRF \& SMRF

From Table 4 Comparison of $10^{\text {th }}$ storey deflection for OMRF \& SMRF structures in $\mathrm{Z}$ directions

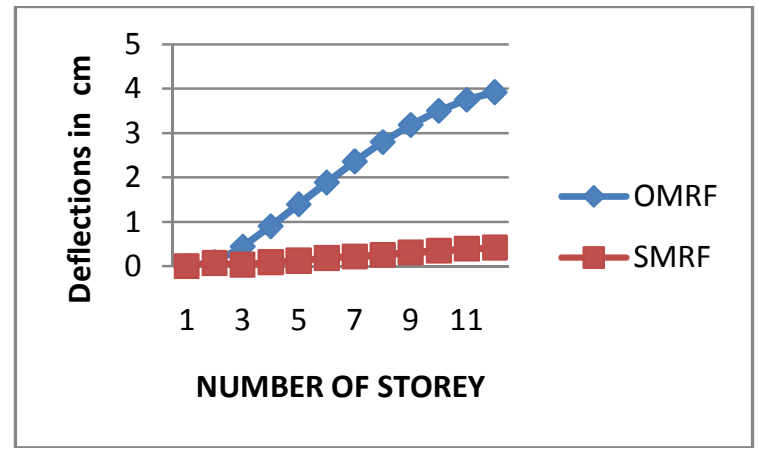

Figure 7 Deflections for OMRF \& SMRF

From the above results that are taken from the story drift, the values for $10^{\text {th }}$ storey structure the deflection that are coming from the OMRF structures are not more safer when compared to SMRF structure

From Table 5Comparison of $15^{\text {th }}$ storey deflection for OMRF \& SMRF structures in $\mathrm{X}$ directions

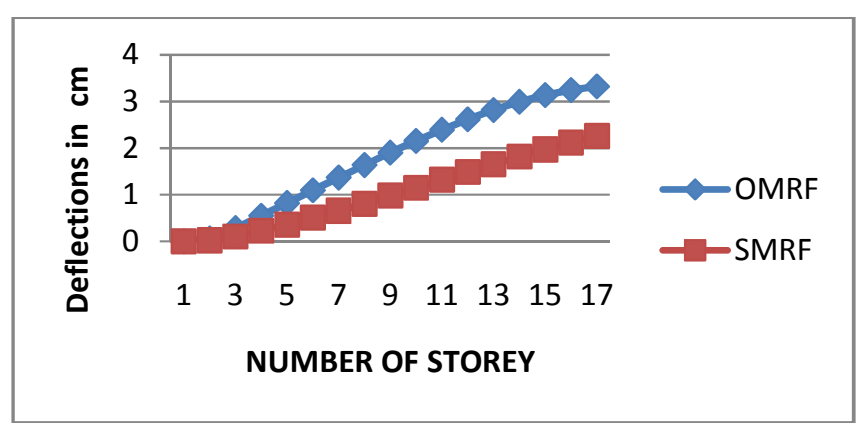

Figure 8 Deflections for OMRF \& SMRF
From Table 6 Comparison of $15^{\text {th }}$ storey deflection for OMRF \& SMRF structures in $\mathrm{Z}$ directions

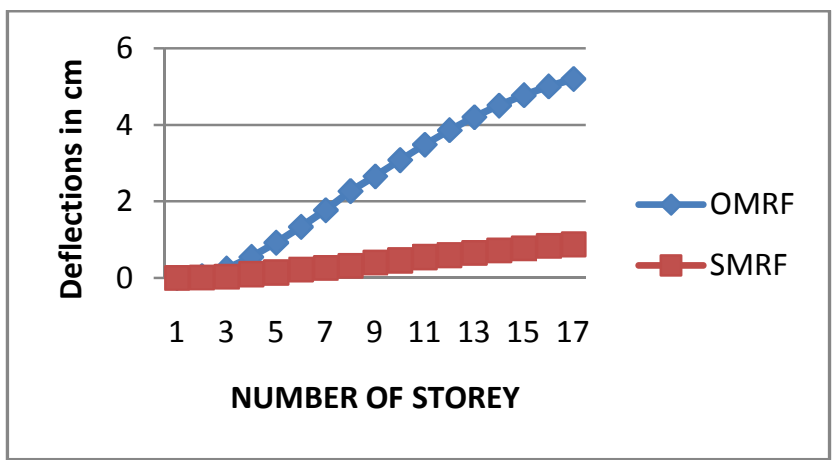

Figure9 Deflections for OMRF \& SMRF

From the above results that are taken from the story drift, the values for $15^{\text {th }}$ storey structure the deflection that are coming from the OMRF structures are not more safer when compared to SMRF structure

From Table 7 Comparison of $20^{\text {th }}$ storey deflection for OMRF \& SMRF structures in $\mathrm{X}$ directions

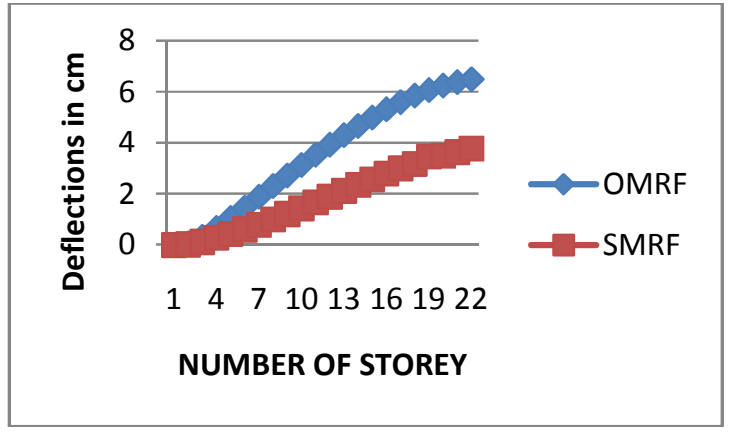

Figure 10 Deflections for OMRF \& SMRF

From Table 8 Comparison of $20^{\text {th }}$ storey deflection for OMRF \& SMRF structures in $\mathrm{Z}$ directions

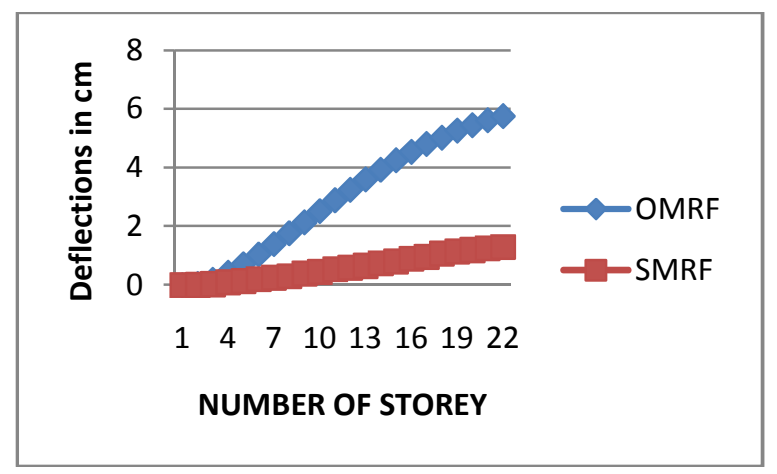

Figure 11 Deflections for OMRF \& SMRF 
From the above results that are taken from the story drift, the values for $20^{\text {th }}$ storey structure the deflection that are coming from the OMRF structures are not more safer when compared to SMRF structure

\section{COMPARISON OF $\%$ OF STEEL REINFORCEMENT REQUIRED FOR OMRF \& SMRF STRUCTURES}

Table9 comparison of $\%$ of steel reinforcement required

\begin{tabular}{|c|c|c|c|c|}
\hline \multirow{2}{*}{ S.No } & \multirow{2}{*}{ Storey } & \multicolumn{2}{|c|}{$\begin{array}{c}\text { Total weight of steel in } \\
\text { Ton }\end{array}$} & $\begin{array}{c}\text { Of steel } \\
\text { variation w.r.t. } \\
\text { OMRF } \\
\text { structure }\end{array}$ \\
\cline { 3 - 4 } & & OMRF & SMRF & \\
\hline 1 & 5 & 29.25 & 32.5 & 9.23 \\
\hline 2 & 10 & 45.55 & 53.55 & 14.93 \\
\hline 3 & 15 & 86.65 & 96.97 & 10.64 \\
\hline 4 & 20 & 120.52 & 136.25 & 11.51 \\
\hline
\end{tabular}

\section{\% of steel variation variation with respect to OMRF structure}

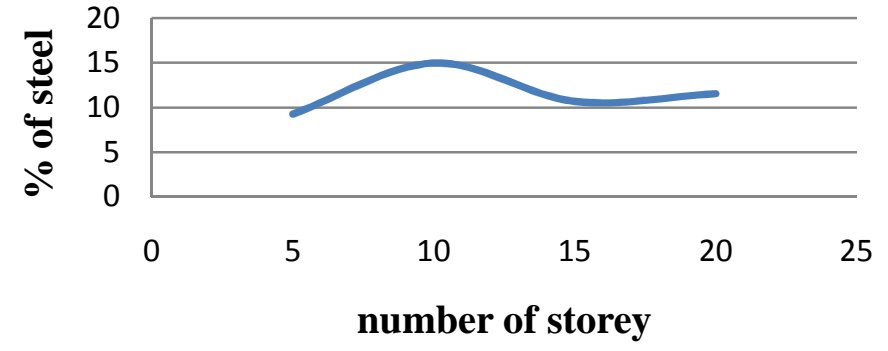

From this comparison the percentage of steel for different floors are listed above and. The OMRF structures need more reinforcement when compared to SMRF structure.

\section{Minimum Reinforcement Detailing For Columns}

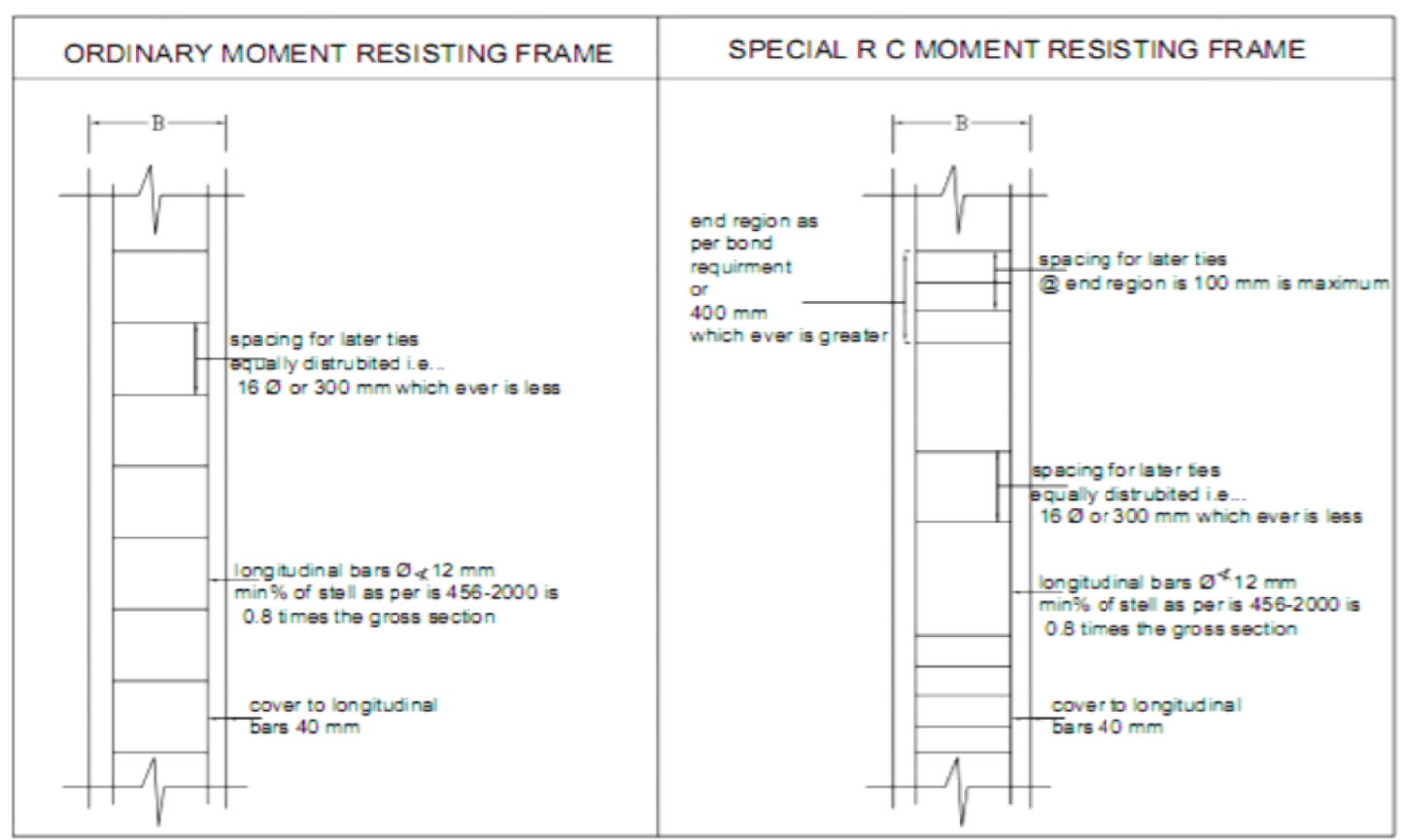

The minimum $\%$ of steel for the columns as per IS $456-2000 \&$ the ductility requirement as per SP 34. 


\section{SUMMARY AND CONCLUSION}

The present study involves the development of a new method and analysis of shear wall framing system and a new model to compare the safety of the structure and cost effectiveness structure for a lateral loading system for a tall $\&$ high raise structures.In this project the behavior of OMRF \&SMRF structures was studied under seismic loads. The lateral loads, dead loads, live load are taken for design of structure as pre IS standards for Visakhapatnam region or Zone II.This SMRF system is cost effective and resisting to tall and high rise structures. Now a day's Visakhapatnam is a rapidly growing city in $20^{\text {th }}$ century the study is based on the past history of earth quake in.A Typical model was done for Serviceability of OMRF \& SMRF systems will be valuable tool for a decision makers. Engineers, in particular this will be able to select economic framing system which will also results in safety of structure \& cost effective of the structures. These structures are the more competitive structures $\&$ challenging structures in the construction field.The areas falling in seismic zone I in the current map are merged with those of seismic zone II. Also, the seismic zone map in the peninsular region is being modified. Madras will come under seismic zone III as against zone II currently. The national Seismic Zone Map presents a large scale view of the seismic zones in the country. Local variations in soil type and geology cannot be represented at that scale. Therefore, for important projects, such as a major dam or a nuclear power plant, the seismic hazard is evaluated specifically for that site. Also, for the purposes of urban planning, metropolitan areas are microzoned. Seismic microzonation accounts for local variations in geology, local soil profile, etc

Based on the analytical study carried out for 4 structures using STAAD.PRO software the following conclusion are:

Analysis of shear wall using a four noded plate element gives stress contour it gives a better results to design a structure.

$\checkmark$ The study gives a comparison of the OMRF \& SMRF structure system under seismic load. SMRF gives a more safety to designers to design the structure and it is little bit cost effective to the builders who construct the tall and high rise buildings

$\checkmark \quad$ In both system of analysis results of OMRF \& SMRF, the storey drift is within permissible limit as per IS (1893 part1,clause no 7.11.1), but when compared with OMRF the SMRF structure having less story drift so the structure can resists the seismic loads more than the OMRF.

$\checkmark \quad$ The min $\%$ percentage and spacing of the lateral ties at beam column joint is different from OMRF \& SMRF structure and so that the lateral deflections that are coming from is less.

$\checkmark$ The structure will be safe when it is subjected to seismic loads in SMRF so that the life of the structure will be also increase because it will resist the lateral loads.

$\checkmark \quad$ Due to falling of zone, The changing of zone to another zone (ref to IS 1893-1962,1893-1966,1893-1970,18932002) the seismic risk will also increase. The SMRF structure plays an important role and having best serviceability and gives more life span to the structure.

\section{REFERENCES}

[1] Akis,Tolga" Lateral Load Analysis Of S Hear WallFrame Structures "department of engineering sciences

[2] Adamantia Athanasopoulou "Shear Strength And Drift Capacity Of Reinforced Concrete And HighPerformance Fiber Reinforced Concrete Low-Rise Walls Subjected To Displacement Reversals"

[3] Anshuman. S, Dipendu Bhunia, Bhavin Ramjiyani."Solution Of Shear Wall Location In MultiStorey Building".

[4] Anshuman. S, Dipendu Bhunia, Bhavin Ramjiyani."Solution of shear wall location in multistorey building"

[5] Chopra, A. K., Dy namics of Structures , Second Edition, Prentice Hall, 2000

[6] Clough.R.W., King,I.P.andWilson, E. L., "Structural Analysis of Multistorey Bu ildings", Journal o f Structural Division, ASCE, 90 (19), 1964.

[7] Cook.R.D., "Avoidance of Parasitic Shear in Pl ane Element", Journal of Structural Division, ASCE, 101 (6), 1975.

[8] CIRES \& Geological Sciences University of Colorado http://www.colorado.edu/GeolSci

[9] Donovan, N.C., Earthquake Hazards For Buildings, In Building Practice For Disaster Mitigation, National Bureau Of Standards Building Science Series 46, 1973, Pp 82-111.

[10] Epackachi.S,Esmaili.O,M,Mirghaderi.R, and Taheri,"Review on SeismicRehabilitation of a 56-Story RC Tall Building having Shear Wall System Based on a NonlinearDynamic Performance Evaluation".

[11] Govindu Vanum And Kiros Meles Hadgu Land Use/Land Cover Changes Through The Applications Of Gis And Remote Sensing And The Implications On Sustainable Land Management.

[12] Guidelines For High Rise Buildings- Regarding No. 21270/2008- Ia.Iii Ministry Of Environment \& Forests Government Of India.

[13] Han-Seon Lee \& Dong-Woo Ko" Journal Of The Computational Structural Engineering Institute Of Korea."

[14] Jagannadha Rao .M., Syam Kumar .J, Surya Prakasa Rao .B And Srinivasa Rao .P., 2003 Geomorphology And Land Use Pattern Of Visakhapatnam UrbanIndustrial Area. 
[15] Khan.F.R. and Sbarounis (1964), “ Interaction of Shear Walls and Frames", Journal of the Structural Division, Proc.,ASCE

[16] IS : 875 (Part 1) - 1987" Code Of Practice For Design Loads (Other Than Earthquake) For Buildings And Structures"

[17] IS : 875 ( Part 2 ) - 1987 Code Of Practice For Design Loads (Other Than Earthquake) For Buildings And Structures

[18] IS:1893-1984 Criteria For Earthquake Resistant Design Of Structures

[19] IS 1893 ( Part 1 ) :2002 Criteria For Earthquake Resistant Design Of Structures

[20] Lalithkumar.B.V.K.,Ramarao.G.V., SrinivasaRao. K. Department Of Civil Engineering, Andhra University International Journal Of Earth Sciences And Engineering"Seismic Hazard Analysis Of Visakhapatnam, India: Deterministic And Probabilistic Methods"

[21] Learning Earthquake Design And Construction By C.V.R.Murty Indian Institute Of Technology Kanpur Kanpur, India

[22] Misam Abidi, Mangulkar Madhuri. N. "Review On Shear Wall For Soft Story High-Rise Buildings"

[23] Oliver et al."Nonlinear analysis of R/C shear walls subjected to seismic loadings"

[24] Research Engineers International, STAA D.P ro 2006 Techn ical Reference - 2004.

[25] Rasool. Sk , M.E Thesis 2011 "Cost Effective Structural System For Tall And High Raise Buildings Subjected To Earth Quake"

[26] Sang Whan Han,N.Y.Jee "Seismic behaviors of columns in ordinary and intermediate moment resisting concrete frames"

[27] Smith, B. S. and Girgi s, A, "Simpl e Analogous Frames for Shear Wall Analysis", Journa 1 of Structur al Division, ASCE, 110 (11), 1984.

[28] Shahabodin ,Zaregarizi "Comparative Invegestation On Using Shear Wall And Infill To Improve Seismic Performance Of Existing Building"

[29] sp-34 hand book on concrete reinforcement and detailing

[30] Venkatesh.S.V..Sharada bai. ,H, "Effect of internal \& external shear wall on performance of building frame subjected to lateral load".

[31] Varyani. U.H. "Analysis Of Design Of Tall Buildings"

[32] "Visakhapatnam City Development Plan" Report Given By GVMC

[33] Wen. Y. K. and Song. S.H..'Structural Reliability / Redundancy under Earthquakes" .Journal of Structural Engineering,

[34] Yadav.S.S, “Computer Aided Analysis ,Design And Estimation Of Multi Storied Structures"

[35] Zhao and Abolhassan Astaneh-As "Seismic Behavior of Composite Shear Wall Systemsand Application of Smart Structures Technology" 